\title{
Az Európai Unió jövője - célok, identitás és kommunikáció
}

\author{
A római szerződés aláírásának 60 . évfordulójára rendezett \\ Jean Monnet-konferencia, Róma, 2017. március 23-24.*
}

Az Európai Bizottság konferenciát rendezett abból az alkalomból, hogy hatvan évvel ezelött, 1957. március 25-én írták alá az Európai Gazdasági Közösség létrehozásáról szóló római szerződést. Az európai integrációval foglalkozó tanácskozás az Európai Unió müködését jellemző problémákkal, az integráció előtt álló célokkal és a megoldandó kérdések megvitatásával foglalkozott. Az alábbiakban a konferencián elemzett témakörökről és a megfogalmazott javaslatokról kívánunk áttekintést nyújtani, ezáltal egyfajta helyzetképet adva az Európai Unióról való gondolkodás során napjainkban felvetődő kérdésekröl.

A konferencia résztvevőit az olasz külügyminisztérium nevében köszöntő Marcella Zaccagnio beszédében rámutatott arra a növekvő szakadékra, amely az állampolgárok és az EU között alakult ki: az unió értékei kívülről és belülről is fenyegetettek. A tagállamok vezetőinek ünnepi találkozóját két nappal megelőzően Zaccagnio hangsúlyozta, hogy ilyen helyzetben nagyon lényeges, hogy a tagállamok az évforduló alkalmából kiadott Római nyilatkozatot egyhangúan elfogadják. E nyilatkozat ugyanis hitet tesz a közös célkitüzések mellett, amelyeket négy fö témakör köré lehet csoportosítani: 1. biztonságos Európa; 2. fenntartható Európa, amelyet összehangolt belsö piac és strukturális reformok jellemeznek; 3. szociális Európa, amelyben tagállami szociális rendszerek működnek, de közösen harcolnak a munkanélküliség ellen és az egyenlö szociális jogokért; 4. nemzetközi szinten erősebb Európa, amely szövetségeket köt a világban. A nyilatkozatnak - amelyet március 25 -én valóban aláírtak - talán a legfontosabb gondolata az, hogy a tagállamok a közös érdekek és értékek védelmében együtt kívánnak fellépni, és a célok eléréséhez az Európai Uniót tartják a megfelelő keretnek (EiT [2017]).

Mikel Landabaso Alvarez, az Európai Bizottság Kommunikációs Főigazgatóságának igazgatója úgy véli, az EU a legjobb példája a sikeresen megvalósított többszintű

* A Jean Monnet Seminar. The future of Europe: A commitment for You(th) címü konferenciára 35 országból érkezett 70 Jean Monnet-professzor. Ez a konferencia jelentette a római szerződés aláírásának évfordulójára rendezett európai uniós szintű rendezvények közül a tudományos élet képviselőinek részvételével lezajlott legfontosabb eseményt. Magyarországról a cikk szerzője kapott meghívást a részvételre.

A kézirat első változata 2017. május 10-én érkezett szerkesztőségünkbe.

DOI: http://dx.doi.org/10.18414/KSZ.2017.6.661 
kormányzásnak. Felhívta a figyelmet arra, hogy nem véletlenül kapott Nobel-békedíjat az integráció, hiszen a demokrácia, az emberi jogok megszilárdításában, valamint a tolerancia és a nyitottság megteremtésében óriási eredményeket ért el. Feltette a kérdést ugyanakkor, hogy a békén és a megbékéltetésen kívül mit tudunk felmutatni. Alvarez emlékeztette a konferencia résztvevőit, hogy az EU rendelkezik a világ legnagyobb egységes belső piacával, a világ GDP-jének 22 százalékát, a világkereskedelem 16 százalékát adja, miközben népessége a világ összlakosságának csak 6 százaléka. Az EU és tagállamai a világ legnagyobb fejlesztésisegély-donorai: az összes segély több mint felét nyújtják. Emellett az EU a globális éghajlatváltozás elleni küzdelemben élenjáró szerepet tölt be, mind a kiotói, mind a párizsi vállalások terén meghatározó szerepet játszott. A kommunikációs igazgató utalt egy felmérésre, amely szerint a fiatal generáció 60 százaléka erősebb uniós szintü döntéshozatalt tartana kívánatosnak. Ehhez kapcsolódóan hangsúlyozta, hogy az Európai Bizottság feladata, hogy megadja az Európa jövőjéről folytatott vitához a szükséges információkat.

\section{Célok, értékek és az információk eljuttatása}

A konferencia vitaindító elöadását Anthony L. Gardner, az EU-hoz akkreditált korábbi amerikai nagykövet tartotta. Elöadásának elején Gardner rámutatott arra, hogy az Európai Unió nem bízik eléggé önmagában. Az EU vezetőinek beszédei jellemzően védekező jellegűek és a problémákról szólnak - ehelyett sokkal inkább a konkrét eredmények megismertetésére lenne szükség. Gardner szerint ehhez hozzájárul az a jelenség, hogy több tagállam nem érzi magát igazán az EU részének, közös vállalkozás helyett ellenségként tüntetik fel az uniót: mindenért „Brüsszelt” okolják, és ami jól megy, azt nemzeti érdemként mutatják be. Az állampolgárok az EU-t a rossz hírekkel azonosítják. Hiányzik az európai szolidaritás több országban, és ha folyamatosan lejáratják az EU-t, akkor ennek az lesz a következménye, mint a brexitről szóló népszavazásé. A nagykövet fontosnak tartaná, hogy közös ideák és ideálok mentén „európaiakat kellene csinálni”, megteremtve az európai identitást. Rámutatott, hogy ez az Egyesült Államokban is nehéz volt, nem lehetett nemzetiségi, faji alapon létrehozni az amerikai identitást, csakis a közösen vállalt értékek iránti szolidaritás alapján.

A nagykövet az európai integráció legfőbb eredményének azt tartja, hogy a demokrácia és a stabilitás létrejött, és elképzelhetetlen lenne a tagállamok közötti háború. Úgy gondolja, hogy az EU-nak köszönhető előnyöket nem jól tárják a nagyközönség elé, ezek nem igazán tudatosulnak az emberekben. Meglátása szerint ilyen előny az egységes piac; az emberek szabad mozgása, az euró által teremtett átlátható és árfolyamkockázatoktól mentes piac, az éghajlat- és környezeti politika, az élelmiszer-biztonság, a $\mathrm{K}+\mathrm{F}$-tevékenység támogatása, az olcsóbb telekommunikációs szolgáltatások vagy a légi közlekedési piac liberalizálásának köszönhető olcsóbb repülőjáratok.

Ahhoz, hogy az EU-nak köszönhető eredményeket és változásokat jobban megismerhessék az európai polgárok, jogszabályi változásokra lenne szükség. Vagyis ugyanúgy, ahogy a strukturális alapokból támogatott beruházások esetében kötelező a tájékoztató táblák közzététele, az üzleti szektor szereplőitől is több ilyen jellegü 
kötelezettséget kellene megkövetelni. Például a roamingdíjak csökkentését vagy eltörlését egyes cégek úgy állítják be, mintha ez az ő döntésük lett volna, pedig uniós szabályozás miatt kellett megtenniük; vagy az élelmiszerekre vonatkozó elöírások esetében is világosan meg kellene jelennie az uniós kötelezettségek betartásának; vagy a százezer eurós bankbetét-garanciát sem maguktól vállalták a bankok, hanem EU-előírás teszi kötelezővé. Gardner az EU-t érintő pozitív gondolatok megerősítését kulcsfontosságú kérdésnek tartja - szerinte ez lenne az uniós intézmények egyik fő feladata.

Az Európa jövőjéről szóló kerekasztal-beszélgetésben Stefano Maullu, az Európai Parlament Kulturális és Oktatási Bizottságának alelnöke kifejtette, hogy az integráció jövöjéről folytatott vitában az egyetemek és az Erasmus-program kulcsszerepet töltenek be. Felhívta a figyelmet, hogy egymás között és a világban is hidakat kell építeni. A többsebességes Európa töredezett, megosztott Európát jelent, amit el kellene kerülni.

Renaud Dehouse, a firenzei European University Institute rektora szerint az európai integráció problémák megoldására adandó válaszok megfogalmazásával kezdődött, és ezt kell most is folytatni: közös válaszokat kell találni és megvalósítani. Dehousse rámutatott arra, hogy a mai fiatalok nagyon kritikusak, az őket érintő problémákkal kellene foglalkozni. Öket alapvetően nem a múltban elért eredmények érdeklik, hanem például az, hogy miként lehetne előmozdítani a gyorsabb gazdasági fejlődést, az új munkahelyek megszületését.

Sneska Quaedvlieg-Mihailovic, az Europa Nostra fötitkára szerint már Jean Monnet is azt mondta, hogy a kultúra területén kellene elkezdeni az együttmüködést - még ha ez nem is így valósult meg akkor, most is erre lenne szükség. A fótitkár felhívta a figyelmet, hogy a Juncker-féle fehér könyv továbbra sem ad víziót (EB [2017]), és hiányzik annak világos megfogalmazása, hogy mitől kellene „megmentenünk” Európát. ${ }^{1}$ Ugyanakkor fontosnak tartja, hogy a következő esztendőt a kulturális örökség európai évévé nyilvánították.

A kerekasztal-beszélgetést követően az egymással párhuzamos három munkacsoportban folyó vita megalapozásához mindegyik munkacsoport témaköréhez kapcsolódóan felvezető gondolatok megfogalmazására került sor.

Az első munkacsoport az Európai Unió reformja során alkalmazandó módszerek megvitatását tüzte ki célul. Ken Endo, a sapporói Hokkaido Egyetem professzora a reformról való gondolkodási keretek kapcsán arra hívta fel a figyelmet, hogy a válság soktényezős, és másfajta, mint a korábbi válságok. Itt egy széles körű összefüggésben kell válaszokat találni arra a feszültségre, amely a globalizáció-demokráciaszuverenitás hármasa között áll fenn. A középréteg vékonyodik, lecsúszik, mert a globalizáció vesztesei innen kerülnek ki, és ez kihatással van a mérsékelt középpártok súlyának csökkenésére, amelyek a nemzetközi együttmüködés hívei. Erre a „strukturális" problémára kellene megoldásokat találni.

\footnotetext{
${ }^{1}$ Az Európai Bizottság által készített dokumentum öt forgatókönyv keretében mutatja be az európai integráció előtt álló lehetőségeket, attól függően, hogy milyen utakat választanak a tagállamok az együttműködés jövőbeli folytatása során (a fehér könyvet lásd $E B$ [2017]).
} 
Nikolas Moes, a European Horizons projekt vezetője saját kezdeményezésének mozgatórugóit ismertette, amelynek keretében egy olyan transzatlanti diákhálózatot hoztak létre, ahol az európai szakpolitikákkal kapcsolatos javaslatokat fogalmaznak meg. Az egész kezdeményezésük abból a felismerésből indult, hogy hiányzik az ifjúság és az Európai Bizottság közötti párbeszéd. Saját tudományos tevékenységet folytatnak, folyóiratot indítottak, a közösségi médiában aktívan részt vesznek, és konferenciákat szerveznek.

A második munkacsoport témája az állampolgárok, a tudományos élet és a fiatalok szerepének vizsgálata volt az Európai Unió jövőjének alakításában. A vita megalapozásaként Jörg Monar, a College of Europe rektora arra mutatott rá, hogy az EU egy projekt, nem ország, ezért lényeges, hogy az uniós állampolgárok bízzanak az EU-ban, mert itt nincs nemzeti hovatartozás alapján megragadható identitás. Az EU-val csak akkor lehet azonosulni, ha előnyös a benne való részvétel, az állampolgárok nyertesei az integrációnak. A globalizáció és digitalizáció korában sok állampolgár fél attól, hogy vesztese lesz a változásoknak. Az EU-nak olyan kereteket kell teremtenie, hogy ezeket a félelmeket kezelje, megoldásokat találjon rájuk. Egyelöre ennek pont az ellenkezője valósul meg, mert az állampolgárok az EU-t a globalizáció leképeződésének tartják. Monar arra is felhívta a figyelmet, hogy az EU-tól közvetlenül nem jutnak el az információk, mert azokat a nemzeti média (tv-csatornák, újságok stb.) és a nemzeti pártok „megszürik”. Véleménye szerint a kamarák, szövetségek fontos szerepet tölthetnének be az EU-ról szóló információk terjesztésében, emellett a rektor nemzeti akciótervek megfogalmazását tenné kötelezővé, amelyek végrehajtását az Európai Bizottságnak kellene ellenőriznie. A tudományos élet szerepe kapcsán rámutatott arra, hogy egyre komplexebb kérdéseket egyre mélyebben kell elemezni, ezért a tudomány szerepe vitathatatlan az európai integráció jövőjéről folytatott gondolkodási folyamatban. Ugyanakkor a kutatók elemző és kritikus hozzáállásából adódóan a legtöbb tudományos munka értelemszerủen csak a problémákról szól. Így úgy tünhet, hogy csak problémák vannak - ezért lényeges szempontnak kellene lennie, hogy a teljes képet vizsgáljuk.

Ecem Oskay az Erasmus Hallgatói és Alumni Egyesület (The Erasmus Students and Alumni Association, ESAA) képviseletében az oktatás társadalmi integrációban betöltött kiemelkedő szerepéről beszélt, és rámutatott a tolerancia, illetve az idegengyűlölettel szembeni fellépés fontosságára. Az európai identitás meghatározója a nyitottság, amelynek a menekültek befogadása során is érvényesülnie kell. Az Erasmus-programot az európai integráció szempontjából az egyik legfontosabb személyes tapasztalatszerzést előmozdító kezdeményezésként értékelte az előadó, amely a benne részt vevő fiatalok számára jobb munkaerőpiaci pozíciót biztosít, fejleszti a kulturális kompetenciát, és az egyéni képességek, az önállóság és az önbizalom erősítését is előmozdítja.

A harmadik munkacsoport témája az Európai Unióról szóló információk eljuttatása a nehezen elérhető társadalmi csoportokhoz volt. Emmi Itaranta regényíró és újságíró arra mutatott rá, hogy az elmúlt évtized gazdasági válsága miatt az EU-t a megszorításokkal azonosították, miközben Európa a béketeremtésröl szól. Felhívta 
a figyelmet, hogy a mai információs társadalomban a közösségi média a szakértői véleményeket mellőzve, manipulált álhírek terjesztését teszi lehetővé. Az EU-nak a társadalmi igazságosságot kell előmozdítania, mert ez teremtheti meg az azonosulást: az igazságot és a tényeket kell „megmenteni”. A demokrácia és az emberi jogok megvédése csak így lehetséges.

Olena Kryvunda, a European Voluntary Service képviselöje - kapcsolódva Itaranta gondolataihoz - az igazság és a hazugság megkülönböztetésére való képesség fejlesztésének fontosságát hangsúlyozta. Ebben az oktatásnak kiemelkedő szerepe van. Ugyanakkor az oktatás során nemcsak szakmai ismereteket kell átadni, hanem olyan társadalmi értékeket is közvetíteni kell, mint a tolerancia vagy a társadalmi befogadás. A nem formális oktatás is nagyon lényeges szerepet játszik a tanulásban. Az önkéntesség, a civil és az ifjúsági szervezetek a legjobb kommunikációs csatornák. Saját példáját említve rámutatott a rádiócsatornákon kezdeményezett vitamüsorok jelentőségére vagy például az általános iskolások számára rendezett mühelyfoglalkozások szerepére.

\section{Vita a reform kereteiről és módszereiről}

Az első munkacsoportban folytatott vita elején a munkacsoport moderátora, Yves Bertoncini, az Európa Mozgalom Francia Tanácsának elnöke, a Delors Intézet igazgatója azt az átfogó kérdést tette fel, hogy mit is kellene megreformálni: a politikákat vagy az intézményrendszert? Luiza Bialasiewicz Jean Monnet-professzor, a munkacsoport raportőre ehhez azt füzte hozzá, hogy arról is kellene vitázni, hogy kiért, mit és miért reformálunk?

A hozzászólók nagyon sokféle szempontot vetettek fel a vita során. Volt, aki arra hívta fel a figyelmet, hogy az euróövezet megfelelö müködése az integráció további fejlődésének kulcskérdése: a lassú növekedésre és a magas munkanélküliségre kell válaszokat találni. Mások arról beszéltek, hogy az Európai Parlamentnek egyre nagyobb a hatásköre, de egyre kevesebben vesznek részt az EP-választásokon - így legitimációja egyre gyengébb.

További hozzászólók a technokrata és bürokratikus vezetési módot bírálták, demokratikusabb keretek és formák megteremtését sürgették, hangsúlyozták, hogy az állampolgári jogokat, a gazdasági és szociális jogokat garantáló alkotmányos megközelítést kell megerösíteni. Megállapították, hogy az európai konstrukció nem teljes: erősebb EU-ra lenne szükség, nagyobb költségvetéssel, közös fellépéssel. A szolidaritásnak és a szubszidiaritásnak egyszerre kell érvényesülnie. Felhívták a figyelmet arra a feloldhatatlannak látszó demokratikus dilemmára, amikor az egyik tagország állampolgárainak többségi véleménye nem egyezik meg egy másik tagország többségének véleményével. Ilyenkor valóban az EU jelmondata: „Az egység a sokféleségben” megközelítés jegyében lehet elörelépni, de kérdés, hogy hogyan.

Szó volt még gradualizmusról (a „Monnet-módszerről”), az alkotmányozási kezdeményezések elbukásáról. A politikai együttmüködést tovább kellene mélyíteni a biztonság erősítése érdekében, másrészt a gazdasági integráció terén a költségvetési unió megteremtését kellene megcélozni a jelenlegi gazdaságpolitikai koordináció helyett. 
Új módszert is sürgettek az európai választásokon, mert az állampolgárok hazai pártokra és alapvetően belpolitikai problémákra szavaznak. Felvetették, hogy az EP-képviselők közvetlen választása helyett meggondolandó lenne a nemzeti parlamenti képviselők kettős mandátumának bevezetése, ami visszalépésnek tünhet, de ezzel megszüntethető lenne az a feszültség, ami a Tanács és a Parlament között húzódik, mert ugyanaz a legitimáció/felhatalmazás állna az EP és a nemzeti parlamenteken keresztül a kormányok mögött.

\section{A záróülés következtetései}

A konferencia záró plenáris ülésén a három munkacsoportban párhuzamosan lefolytatott vita összegzésére került sor. A már idézett Luiza Bialasiewicz, az első munkacsoport raportőre összefoglalásában hangsúlyozta, hogy a vita rámutatott arra, hogy világossá kell tenni, melyek a reform indokai. Feltette a kérdést, hogy eljött-e az alkotmányozási pillanat, vagy a fokozatosság a követendő módszer. Az alkotmányozás az intézményi reformokat és az európai értékek újrafogalmazását jelentené. Lehetséges az a válasz is, hogy nem szükségszerüen kell reformálni, hanem inkább az EU tevékenységét kellene jobban megértetni, közvetíteni.

A második munkacsoport raportőre, Maria Stoicheva Jean Monnet-professzor, a Szófiai Egyetem rektorhelyettese hangsúlyozta, hogy az egyetemeknek kiemelkedő a jelentőségük és felelősségük Európa jövőjének alakításában, a helyi közösségek (az állampolgárok, a tudományos élet és az ifjúság) tájékoztatásában. Az egyetemek rendelkeznek a megfelelő tudással, információkkal, ugyanakkor nem megfelelően nyitottak, és nehezen elérhetők az „átlag állampolgár” számára - ezen a helyzeten mindenképpen javítani kell. A brexit tanulságait pozitív módon kell felhasználni: az EU-projekteket jobban kell a nagyközönség elé tárni, a veszélyekre fel kell hívni a figyelmet. Fontos feladat a generációk közötti interakció erősítése is.

A harmadik munkacsoport raportöre, Deborah Reed-Danahay Jean Monnetprofesszor a nehezen elérhető társadalmi csoportok meghatározása kapcsán rámutatott a különböző szempontok szerinti megosztottságra: a vidéki versus városi lakosok, a magasan versus kevésbé képzettek, a fiatal versus idős korosztály vagy a mag-Európa versus a kevésbé fejlett perifériaországok állampolgárai. Az Európai Unióhoz való tartozás érzésének megerősítése leginkább a mindennapi életünkre gyakorolt hatások bemutatásán keresztül lehetséges. Az informális és a formális oktatás is fontos szerepet tölt be, lényeges a civilképzés és a tanárképző kurzusok megerősítése.

A konferenciát záró beszédében Martine Reicherts, az Európai Bizottság Oktatási, Ifjúsági, Sport és Kulturális Főigazgatóságának főigazgatója feltette azt a kérdést: mit kellene másképpen csinálni? Úgy látja, az emberek nem érzik magukénak az EU-t, mert úgy érzik, nem értük van, mert a belső piac, a bankok (vagyis a gazdaság szereplőinek) problémái vannak előtérben, és nem az állampolgárokéi. Éppen ezért Rousseau társadalmi szerződésére utalva, az EU esetében is valamiféle társadalmi szerződésre lenne szükség. Reicherts szerint ennek alappillérei a tudás (az oktatás), az ökológia (a Föld állapota), az emberek (egészségügy, lakhatás, jövedelem) és a kultúra 
lehetnének. A föigazgató végezetül hangsúlyozta, hogy az uniós programok közül az Erasmus kiemelten sikeres és pozitív kezdeményezés, amelynek akár tízszeres költségvetési keretemeléséért is hajlandó lenne küzdeni az EU következő hétéves költségvetési időszakában, ugyanis ez a program járulhat hozzá leginkább ahhoz, hogy a fiatal korosztályban megerősödjön az európai identitás.

\section{Hivatkozás}

EB [2017]: Fehér könyv Európa jövőjéről. A 27 tagú EU útja 2025-ig: Gondolatok és forgatókönyvek. COM(2017)2025, március 1. Brüsszel, https://ec.europa.eu/commission/sites/ beta-political/files/feher_konyv_europa_jovojerol_hu.pdf.

EIT [2017]: A 27 tagállam, az Európai Tanács, az Európai Parlament és az Európai Bizottság vezetőinek nyilatkozata. Római nyilatkozat, március 25 . Róma, http://www.consilium. europa.eu/hu/press/press-releases/2017/03/25-rome-declaration/.

Kengyel Ákos

Kengyel Ákos Jean Monnet-professzor, a Budapesti Corvinus Egyetem Nemzetközi Tanulmányok Intézetének egyetemi docense (e-mail: akos.kengyel@uni-corvinus.hu). 